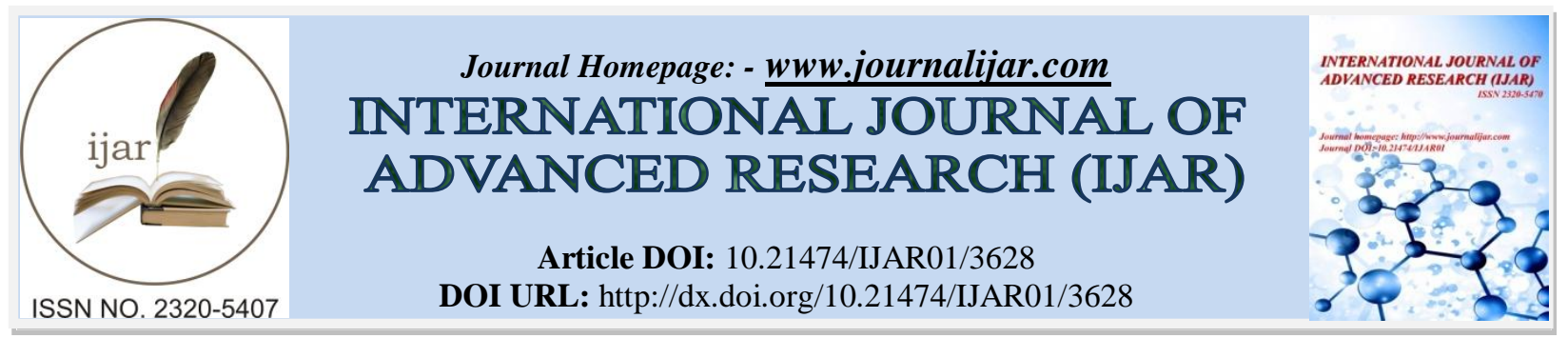

RESEARCH ARTICLE

\title{
STATUS OF INFORMATION AND COMMUNICATION TECHNOLOGY PROGRAMAND NATIONAL ACHIEVEMENT TEST PERFORMANCE OF PUBLIC SCHOOLS IN THE DIVISION OF LAGUNA, PHILIPPINES.
}

Lerma P. Buenvinida ${ }^{1}$ and Rainiel Victor M. Crisologo ${ }^{2}$.

1. College of Teacher Education, Laguna State Polytechnic University, Los Banos,Laguna, Philipppines fax no. (049) 827-0421.

2. Department of Education, Los Banos District, Los Banos, Laguna, Philippines.

\section{Manuscript Info}

[..........................

Manuscript History

Received: 08 January 2017

Final Accepted: 01 February 2017

Published: March 2017

Key words:-

teachers' ICT competency, national achievement test, cluster, basic level, progressing

\section{Abstract}

The study sought to determine the status and indicators of teachers' ICT competency and National Achievement Test performance of pupils; relationship between the teachers' demographic profile and teachers' ICT competency, schools' ICT program and ICT infrastructure. The descriptive correlation survey was adopted and 1,012 teachers from 9 districts in the Division of Laguna were given questionnaire. The statements on competencies were based from the 4 domains of National ICT Competency Standards for Teachers which are social and ethical, technology and operation concepts, pedagogical, and professional domains. The findings revealed that competence on social and ethical, technology and operation concepts, pedagogical and professional domains obtained means were interpreted at basic level. In terms of NAT performance of 42 schools, 17 are big schools and 25 are small schools, only 4 schools obtained Moving-Towards-Mastery (MTM). The status of School's ICT program in selected clusters in terms of Teachers' ICT competence and Curriculum Integration with mean scores of 2.10, and ICT Infrastructure mean of 1.64, with an overall mean of 2.02 was interpreted at Progressing level. The relationship between the teachers' demographic profiles and teachers' ICT competency was found significant, however no significant associations were found between schools' ICT program and ICT infrastructure. All indicators of ICT competency skills of teacher respondents were not significant and did not affect significantly the NAT performance. The school administrators need to provide inservice trainings on ICT, improve schools' ICT facilities to enhance teachers' ICT competency skills and increase level of ICT integration to instruction.

Copy Right, IJAR, 2017,. All rights reserved.

\section{Introduction:-}

The Department of Education (2009) ${ }^{3}$ of the Philippines points that Information and Communication Technology (ICT) must be an integral part of all learning areas, both hardware and software. Hence, according from Department

Corresponding Author:- Lerma P. Buenvinida.

Address:- College of Teacher Education, Laguna State Polytechnic University, Los Banos,Laguna,

Philipppines fax no. (049) 827-0421. 
of Education (DepEd), e-learning and the use and application of ICT must be employed in all subjects because this is now the most viable intervention in educational reform.

DepEd is giving its best to make Computerization Program one of the most functional, if not the greatest program, being implemented at present. The times call for education to aim towards advancement of technology. This can only happen with the installation and use of computers and other equipment which call forth for modern technology and advance learning.

The Human Development Report of the United Nations Development Program or UNDP (2001) states, "ICT is a pervasive input to almost all human activities. It breaks barriers to human development in at least three ways: by breaking barriers to knowledge, by breaking barriers to participation and by breaking barriers to economic opportunity." Even in the daily lives of teachers and school heads, the rapid advances in ICT can create new things such as storing information, retrieving information, handling, distributing and utilizing information. The advancement of ICT according to Ocampo $(2002)^{9}$ is intertwined with globalization and together creates a new paradigm called the network age.

Despite the efforts of DepEd, various studies conducted on limited samples of teachers reflect alarmingly low levels of teacher competency. For instance, a study in 2004 revealed that only 1 out of 7 schools had teachers who were computer literate (Java, 2004) ${ }^{6}$. Two years back, a study found out that seventy-five percent of respondent schools had only 10 percent of their teachers with Internet skills (Tinio, 2002) ${ }^{10}$. These studies reveal a nuance that the teachers are deficient in ICT skills. This necessitates the conduct of a definitive study which seeks to measure the ICT competencies of Filipino teachers.

There is a growing challenge in the Philippines in the appropriate and efficient use of ICT in teaching and learning. With the multitudes of programs launched by both private and public sectors there are questions of what happened, present status, and where the program is heading. The resources poured into ICT in the supply of equipment, access to software, and availability of telecommunication infrastructures, capacity building for teachers, among others have reported to have been made in collaboration with the private sectors specifically Microsoft, Intel, and major telecommunications companies, organizations, and other governmentswith DepEd. (DBM, 2009).

It is imperative to examine the situation of learners and how information and communication tools help them prepare for the real life. This study aimed to analyze the different domains, causes of problems, and relationships that have bearing to the teaching and learning process.Hence, a research entitled Status of Information and Communication Technology Program and National Achievement Test Performance of Public Schools in the Division of Laguna, Philippines was conceived

\section{Research Methods:-}

Sampling Technique. This study was conducted in the Schools Division of Laguna, Philippines. It is composed of 2 selected clusters which are Cluster 2 and 3 with 9 selected districts with 42 selected elementary schools. Specifically, the 9 districts are Los Banos, Victoria, Bay, Magdalena-Majayjay, Cabuyao, Calauan, Alaminos and Cavinti Districts, all are located in the province of Laguna. Primarily, this study relied on the result of the quantitative data gathered. Thus, more number of schools were needed. Since the source of data is mainly quantitative, a large number of respondents were imperative. Purposive random sampling was done in the selection of schools. Central (big school) and non-central (small school) schools from each district where taken as samples. It was purposely chosen to make the findings generalizable to the population where schools from different categories are well-represented. Central and non-central schools were involved in this study to include instances chosen deliberately to reflect diversity on presumptively important dimensions from schools with varied predictors. Schools were not chosen randomly but rather purposively and conveniently.

Respondents of the Study. The 1,012 public elementary school teachers were selected from clustered 9districts in the Division of Laguna. The teachers were taken as the primary respondents because they are the front liners in attaining Quality Education through the use of ICT in their teaching-learning process.

Research Instrument. The survey questionnaire for elementary school teachers on perceived ICT competencies and school's ICT program was used as the main instrument of the study. It was developed, validated and mainly utilized to answer the research questions and to find out the perceived competencies, extent of use and training needs on ICT 
of public school teachers in selected districts in Division of Laguna. Their ICT competencies were measured using the questionnaire and the results of the survey contributed as bases in the National Achievement Test Performance of grade 6pupils and to equip elementary school teachers with knowledge and skills on ICT as an appropriate tool in the teaching-learning process. Part I of the research questionnaire is the respondents' demographic profile. The questionnaire was patterned to several instruments. Part of which described the respondents' background information that includes; age, gender, civil status, family monthly income, highest educational attainment, length of service, position and number of ICT related trainings.Part II of the research questionnaire comprised of statements on competencies based on the 4 Domains of National ICT Competency Standards for Teachers (NICS for Teachers) which are the social and ethical, technology and operation concepts, pedagogical, and professional domains. The said domains and standards were customized to fit in the study. Schools' ICT inventory and checklist were also included to determine the status of schools' ICT program in the Division of Laguna. To gauge the capacity/capability of the Schools Division in terms of emerging, progressing, and advance, the researchers personally interviewed and gave the Division Planning Officer a questionnaire who is in charge of the physical facilities of the whole division. The questionnaire was validated by 3 experts from DepED Division of Laguna. After validating the questionnaire, it was pilot tested with 9 principals, 5 from central schools and 4 from noncentral schools to ensure the reliability, validity and accuracy of the research instrument. It set an accepted level of proficiency by portraying demonstrable activities. These standards were concretized by specific indicators for the implemented questionnaire. These were measured by a Likert scale type of instrument where 1 shows a weak grasp of the indicator and 4 is the highest, showing high proficiency. The responses of the respondents were tabulated and analyzed using the Statistical Software (SPSS). The researcher used descriptive statistical technique to calculate the frequencies, percentage distribution and means and standard deviation of each response to present the details about the teacher profile, ICT competency of the teachers. Independent Sample's T-Test, Pearson, Regression were done to check the significant relationship between perceptions of the respondents in ICT competencies and school's ICT program.

Research Procedure. The researchers sought the permission of the Schools Division Superintendent, district supervisors and school heads of the Division of Laguna. Before the distribution of the questionnaires, the researchers met the administrators and explained to them the purpose of the study. Distribution of the questionnaires to the administrators and their teachers followed. The researchers then administered the questionnaires personally from one school to another in the identified public elementary schools. Documents from the Districts and Schools' Planning Offices were also analyzed to determine the status of schools' ICT program from school years 2011-2014.To answer the research problems, the instrument on ICT competencies, schools' ICT program, and NAT Performance of grade 6were used. The weighted mean and qualitative descriptions were utilized to determine the ICT competencies and ICT capabilities of schools in the division of Laguna. Upon the retrieval of questionnaires, data from elementary school teacher-respondents were quantified. Data analysis and findings of this study hinge primarily upon the results of quantitative data gathered from the surveys. The quantitative data were analyzed using the mean, standard deviation, percentages and frequencies to find out the profile of elementary school teachers as to age, gender, civil status, family monthly income, highest educational attainment, length of service, position and number of ICT related trainings. Mean and SD were used in computing the perceived ICT competencies, and ICT program of schools.

\section{Results and Discussion:-}

Figure 1 shows that a small scale of the respondents are male, from1,012 respondents only 103 are male or $10.2 \%$, while the female comprised $89.8 \%$ with a total of 909 or $89.8 \%$. 


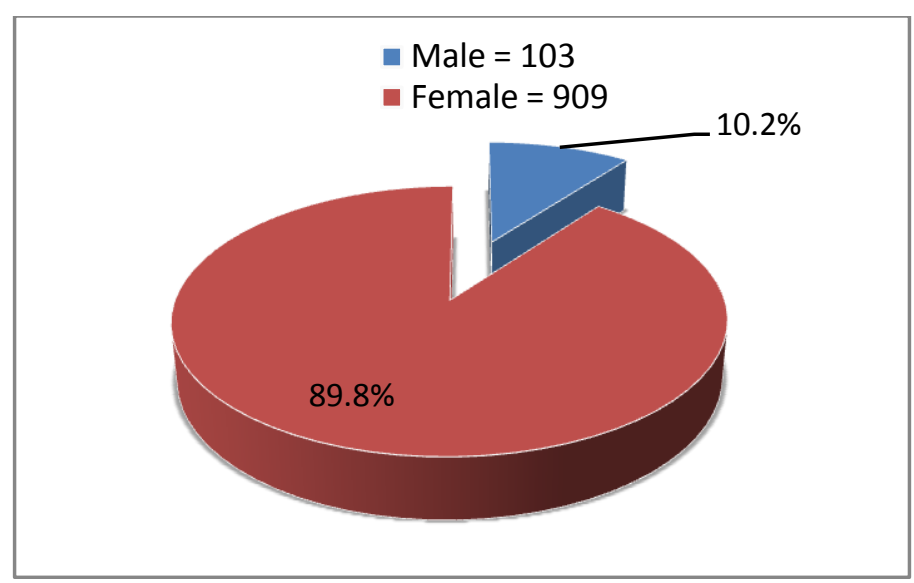

Figure 1:- Distribution of Gender of Teacher-Respondents

As presented in Figure 2, majority are married, comprising of $72.7 \%$ or $736,21.8 \%$ are single, $4.3 \%$ are widow, and $1.1 \%$ or 11 are separated out of 1,012 teacher-respondents.

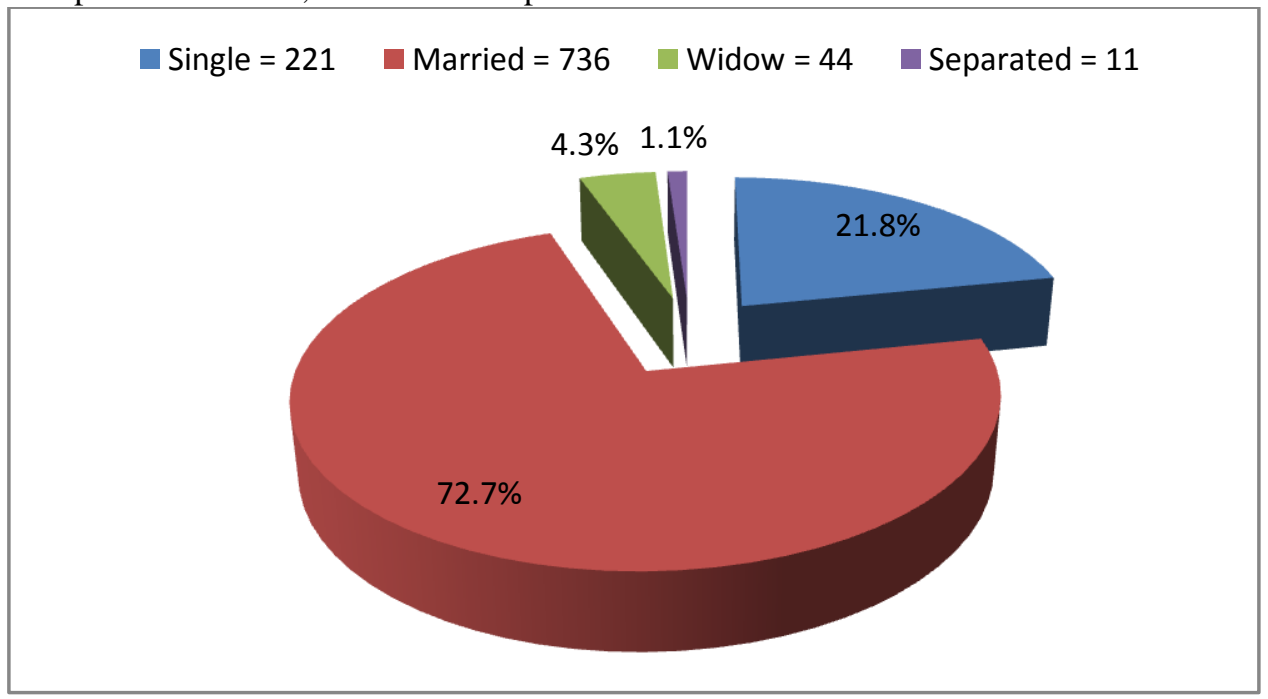

Figure 2:- Distribution of Civil Status ofteacher-respondents

As revealed in Figure 3 ,among the 1,012 respondents, 558 or $55.1 \%$ are in the service for 10 years, while $28.4 \%$ or 287,29 or $2.8 \%$ are in their 31 to 40 years in service and 1 is in the service for 40 years or more. 


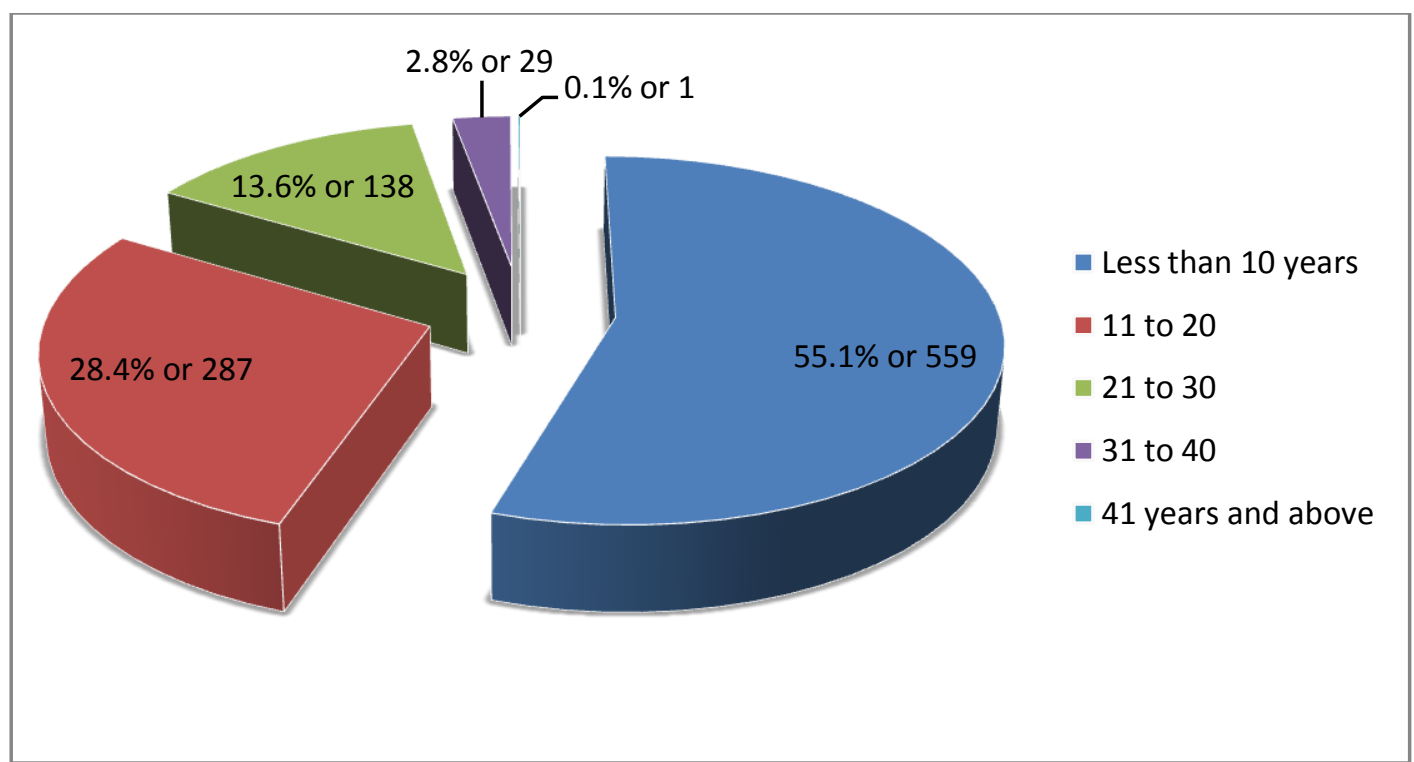

Figure 3:- Length of Service of the teacher-respondents

Table 1:- Level of Mean Perception of Respondents on ICT CompetencySkills

\begin{tabular}{|l|l|l|l|}
\hline ICT COMPETENCY SKILLS & MEAN & SD & $\begin{array}{l}\text { DESCRIPTIVE } \\
\text { INTERPRETATION }\end{array}$ \\
\hline SOCIAL AND ETHICAL AND OPERATION & 2.53 & 0.60 & PROFICIENT \\
\hline $\begin{array}{l}\text { TECHNOLOGY AONCEPTS } \\
\text { PEDAGOGICAL }\end{array}$ & 2.41 & 0.76 & BASIC \\
\hline PROFESSIONAL & 2.2 & 0.75 & BASIC \\
\hline OVERALL & $\mathbf{2 . 3 2}$ & 0.72 & BASIC \\
\hline
\end{tabular}

Legend: 1.00-1.50-Below Basic, 1.51-2.50-Basic, 2.51-3.50-Proficient, 3.51-4.00-Highly Proficient

The respondents' ICT competence on social and ethical with a mean of 2.53 and interpreted as proficient, while technology and operation concepts, pedagogical and professional domains scored 2.41, 2.14 and 2.2, respectively were described as basic. The findings confirmed with the study of Kim and Baylor (2008) ${ }^{7}$ that the use of technology for teaching requires the development not only of knowledge, skills, and behaviors but also of appropriate attitude, social, and ethical foundation.Chang $(2012)^{2}$ posits that to be an experienced and capable technological leader, school administrators such as the principal, must be trained in vision, planning and management, how school reform will be affected by technology and ICT tools and infrastructure support, evaluation and research. Further, according from the study of

Table 2 shows that among 42 schools, only 4 schools have reached Moving-Towards-Mastery (MTM) in the NAT. The school with highest mean percentage score was obtained by C5 S4 (small school) with an MPS of 75.82; followed by C5 S3 (small school) with 69.05 mean percentage score and C5 B2 (big school) with 67.74, and C6 S1 (small school) with 66.29 mean percentages scores ,respectively. 
Table 2:- Mean Percentage Scores of National Achievement Test of Grade 6 in Selected Clustered Districts and Schools

\begin{tabular}{|c|c|c|}
\hline Clustered Districts and Schools & $\begin{array}{l}\text { NAT VI Mean Percentage Scores } \\
\text { (MPS) }\end{array}$ & $\begin{array}{l}\text { Mastery Level Descriptive } \\
\text { Equivalent }\end{array}$ \\
\hline C5 B1 & 60.91 & Average \\
\hline C5 B2 & 67.64 & Moving-Towards-Mastery \\
\hline C5 B3 & 54.70 & Average \\
\hline C5 B4 & 58.28 & Average \\
\hline C6 B1 & 60.06 & Average \\
\hline C6 B2 & 57.63 & Average \\
\hline C6 B3 & 43.35 & Average \\
\hline C6 B4 & 44.32 & Average \\
\hline C6 B5 & 45.97 & Average \\
\hline C7 B1 & 47.77 & Average \\
\hline C7 B2 & 50.92 & Average \\
\hline C7 B3 & 57.41 & Average \\
\hline C7 B4 & 51.08 & Average \\
\hline C8 B1 & 43.31 & Average \\
\hline $\mathrm{C} 8 \mathrm{~B} 2$ & 49.72 & Average \\
\hline C8 B3 & 58.26 & Average \\
\hline C8 B4 & 52.42 & Average \\
\hline C5 S1 & 62.84 & Average \\
\hline $\mathrm{C} 5 \mathrm{~S} 2$ & 50.36 & Average \\
\hline $\mathrm{C} 5 \mathrm{~S} 3$ & 69.05 & Moving-Towards-Mastery \\
\hline C5 S4 & 75.82 & Moving-Towards-Mastery \\
\hline C5 S5 & 58.01 & Average \\
\hline C5 S6 & 65.91 & Average \\
\hline C6 S1 & 66.29 & Moving-Towards-Mastery \\
\hline C6 S2 & 64.55 & Average \\
\hline C6 S3 & 53.07 & Average \\
\hline C6 S4 & 53.70 & Average \\
\hline C6 S5 & 49.13 & Average \\
\hline C6 S6 & 50.67 & Average \\
\hline C6 S7 & 40.17 & Average \\
\hline C6 S8 & 40.72 & Average \\
\hline C7 S1 & 64.10 & Average \\
\hline C7 S2 & 54.21 & Average \\
\hline C7 S3 & 64.67 & Average \\
\hline C7 S4 & 53.86 & Average \\
\hline C7 S5 & 61.88 & Average \\
\hline C7 S6 & 58.20 & Average \\
\hline C7 S7 & 47.37 & Average \\
\hline C8 S1 & 52.38 & Average \\
\hline C8 S2 & 57.20 & Average \\
\hline C8 S3 & 45.97 & Average \\
\hline $\mathrm{C} 8-\mathrm{S} 4$ & 48.12 & Average \\
\hline Overall & 55.05 & AVERAGE \\
\hline
\end{tabular}

Mastery Level Descriptive Equivalent: 0\%-4\% Absolutely No Mastery (ANM), 5\%-14\% Very Low (VL), 15\%-34\% Low (L), 35\%-65\% Average (AVR), 66\%-85\% Moving Towards Mastery (MTM), 86\%-95\% Closely Approximating Mastery (CAM), 96\%-100\% Mastered (M)

With reference to the study of $\operatorname{ELNORD}(2006)^{4}$, ICT generally has a positive impact on learning but the expectations that ICT could in some ways revolutionize processes at school have not been realized. This goes beyond the use of computers by teachers since not only personal computers (PCs) and the Internet but also digital 
cameras, mobile phones and other technologies can help to change teaching processes. The use of ICT is mostly focused on supporting the subject content, hence ICT-based activities by pupils are more time consuming than producing output. Moreover, the impact of integrating ICT in teaching can be measured in pupil engagement, differentiation, creativity and by the fact that less time is wasted, though the impact of ICT is very dependent on how it is used. Headmasters typically view ICT as a valuable tool for pedagogical development but very few of them actually experience this impact

Table 3:- Status of Schools' ICT Program

\begin{tabular}{|l|l|l|l|}
\hline Components of Schools' ICT Program & SD & Mean & Descriptive Interpretation \\
\hline Teachers' ICT Competence & 0.66 & 2.10 & Progressing \\
\hline ICT Infrastructures & 0.48 & 1.64 & Progressing \\
\hline Curriculum Integration & 0.69 & 2.10 & Progressing \\
\hline Overall & 0.49 & 2.02 & Progressing \\
\hline
\end{tabular}

Legend: 1.00-1.50-Emerging 1.51-2.50-Progressing 2.51-3.00-Advanced

Table 3 reveals that the status of Schools' ICT Program in selected clusters are progressing in terms of Teachers' ICT Competence and Curriculum Integration with a mean of 2.10and ICT Infrastructure with 1.64 mean score. Kozma $(2008)^{8}$ acknowledges that ICT strategies in many countries cut across diverse fields. Infrastructure development is necessary in order to ensure access to schools, networks and resources for learning. Teacher training both initial and in-service is a prerequisite for the ability of education to use ICT in learning processes. Curricula and pedagogical approaches may have to be changed in order to cater for educational change with ICT.

Table 4 revealed significant associationsbetween ICT School Program (in terms of teachers competence) and ICT Competency skills in social and ethical, and technology and operation concepts with p-value of less than 0.05.A study conducted by Ministry of Education of Norway (2006) states that the extent of teachers' education has implemented courses and strategies towards the increased competence of teachers in using ICT which is an important part of educational development and change. This could be seen as ICT literacy indicators for teacher education, and of how teachers are prepared to face the challenges in their practice as teachers.

Table4:- Relationship between the Respondents' Perceptions on ICT CompetencySkills and Schools' ICT Program in terms of Teachers' Competence

\begin{tabular}{|l|l|l|}
\hline ICT Competency Skills & Correlation Coefficient & p-value \\
\hline 1 Social and Ethical & 0.316 & $0.041^{*}$ \\
\hline 2 Technology and Operations & 0.293 & 0.059 \\
\hline 3 Pedagogy & 0.137 & 0.387 \\
\hline 4 Professional & 0.216 & 0.170 \\
\hline
\end{tabular}

Table 5 shows that significant associations were not found between ICT School Program (in terms of Schools' ICT Program) and all Respondents' Perception ICT Competency Skills (p value is more than 0.05).

Table 5:- Relationship between the Respondents' Perception on the ICT Competency Skills and Overall Schools' ICT Program

\begin{tabular}{|l|l|l|}
\hline ICT Competency Skills & Correlation Coefficient & p-value \\
\hline 1. Social and Ethical & 0.227 & 0.149 \\
\hline 2. Technology and Operations & 0.249 & 0.111 \\
\hline 3. Pedagogy & 0.060 & 0.707 \\
\hline 4. Professional & 0.112 & 0.479 \\
\hline
\end{tabular}

In accordance to the study of Baylor and Ritchie (2002) ${ }^{1}$, which states that it is useful for school leaders as it underlines the importance of having a shared vision on the place of ICT in education and having a school based ICT policy plan. Such a plan acts as a blueprint for the sequence of goals a school hopes to achieve. It also outlines the overall philosophy of technology use and indicates how ICT will improve teaching and learning.

Table 6:- Relationship between Schools' ICT Program and NAT Performance

\begin{tabular}{|l|l|}
\hline Schools' ICT Program & p-value \\
\hline 1. Teachers' Competence & 0.466 \\
\hline 2. Facilities and Infrastructure & 0.426 \\
\hline 3. Curriculum Integration & 0.203 \\
\hline
\end{tabular}


As could be gleaned in Table 6, the Schools' ICT components were not significant and does not affect significantly the NAT performance. According to Honey $(2005)^{5}$, efforts to integrate technology into schools and classroom practices must not only be acknowledged but also provide evidence that technology assists in meeting these accountability demands. School systems must prove the investments made in technology are improving student scores on standardized tests.

\section{Conclusions:-}

The respondents' ICT competence on social and ethical was describedas Proficient, while technology and operation concepts, pedagogical and professional domains were described as Basic. It is therefore imperative that teachers need to be supported with ICT infrastructure for simulation and blended learning. Since only 4 schools have reached Moving-Towards-Mastery (MTM)level in the National Achievement Test, ICT integration in the basic education curriculum in all learning areas, to wit Mathematics, English, Science, Filipino and Social Studies is recommended. The interactive approaches in the learning process will enhance the performance of pupils in the standardized test administered by theDepartment of Education. The status of Schools' ICT Program in selected clusters are progressing in terms of Teachers' ICT Competence and Curriculum Integration. Significant associations were not found between ICT School Program (in terms of Schools' ICT Program) and all Respondents' Perception ICT Competency Skills. The Schools' ICT components were not significant and does not affect significantly the NAT performance.The school administrators need to provide in-service trainings on ICT, improve schools' ICT facilities to enhance teachers' ICT competency skills and increase level of ICT integration to instruction.

\section{References:-}

1. Baylor, A.L. \& Ritchie, D. (2002). What factors facilitate teacher skill, teacher morale, and perceived student learningin technology-using classrooms? Computers and Education, 39(4), 395=414.

2. Chang, I.H. (2012). The Effect of Principals' Technological Leadership on Teachers' Technological

3. Literacy and Teaching Effectiveness in Taiwanese Elementary Schools. Educational Technology \&

4. Society, 15(2), 328-340.

5. Department of Education. National Education Technology Plan. Retrieved and Accessed: November

6. 2009 from<http://edtechfuture.org/?page_id=8227

7. ELNORD (2006) "eLearning Nordic 2006", Edited by Pedersen, S.G., Malmberg,P., Christensen, A.J.

8. Pedersen, M., Nipper, S. ,Graem, CD., Norrgard, J.\&Ramboll-Management. Copenhagen: Ramboll

9. Management.

10. Honey, M. (2005). Critical Issue: Using Technology to improve student achievement . Retrieved March

11. 12, 2007. From http://www.ncrel.org

12. Java, T. (2004). Technology attitudes, competencies and use in practice teaching: Implications to

13. Pre-service teacher education. Thesis for Master of Arts in Education (Education Technology),

14. College of Education, University of the Philippines, Diliman, Quezon City

15. Kim, C. \& Baylor, A.L. (2008). A Virtual Change Agent: Motivating Pre-service Teachers to Integrate

16. Technology in their Future Classrooms. Educational Technology \& Society. 11(2), 309-321.

17. Kozma, R.B. (2008). 'Comparative analysis of policies for ICT in education',in:J.Voogt\& G. Knezek

18. (eds). International handbook on Information Technology in primary and secondary education.

19. New York:springer

20. Ocampo, P.D. S. (2002). Enhancing Philippine Science \& Technologythru ICT Preface.Transactions

21. of the National Academy of Science and Technology, 24:v-vi.

22. Tinio, V. (2002). Survey of Information Communication Technology utilization in Philippine public high schools. Retrieved on April 2005 from www.digitalphilippines.org/research 